\title{
THE GENETIC COMPONENT OF LANGUAGE
}

\author{
C. D. DARLINGTON
}

John Innes Horticultural Institution, Merton

CONTENTS

Received $16 . x \cdot 47$

1. Determinacy in language

2. The point of attack

3. Genetic premises

4. The views of the linguist

5. The TH sound map

6. The blood gene map

7. Genes in society Summary

\section{DETERMINACY IN LANGUAGE}

THE achievement of two centuries of philology has been, first, to show the family relationships of languages from which evolutionary changes could be inferred and, secondly, to show certain of the laws by which these changes take place. Some of these laws are important in demonstrating a general principle of determinacy; such are the laws of parallel development, both phonetic as in sound shifts and consonantal dissimilation, and grammatical as in loss of gender or inflexion. These laws imply the regular relationship of cause and effect over great areas and great periods of time. Their scope has naturally, although sometimes unduly, impressed linguists with the uniform character of linguistic processes throughout mankind.

There are, however, other laws of development which point to differences amongst men. Such are the principles of the individuality of speech, the local determination of dialect, and the instability of newly transferred or imposed languages. These also demand explanation in terms of cause and effect. But the causes of the differences, no less than the causes of the similarities, must be partly genetic. It is these genetic components whose actions I wish to examine.

\section{THE POINT OF ATTACK}

Languages as organised systems of expression establish, by their cultural influence, those mating groups or rather barriers between groups which, in all sexual organisms, are responsible for the formation of races and species. Languages must have an effect in producing genetic homogeneity within groups ; that effect must be proportional to the time and degree to which the barriers to mating that they set up are effective and other barriers are not. Anthropologists and politicians have therefore had some excuse for identifying race and language. But it has, over most of the world, been a poor excuse owing to the obvious instability of language-race combinations in man. All great empires from the Roman to the Russian have, in 
some measure, communicated their own languages to their subject peoples. The Romance languages cover that part of the Western Empire which has not been submerged by later empires. And the Western Empire was latterly only one-thousandth part descended from the old republic. Language therefore represents the top stratum of conquests ; and many of these conquests have depended on cultural rather than on numerical superiority.

If transferences of language from one people to another had been, or could be, accomplished without change, there would be no ground for inventing or seeking a genetic component of language. But in fact the transferred or imposed language is always altered when the imposing force is removed. How are we to examine these alterations and identify their genetic components? The first step must be to sort out changes in language itself into elements much as, in genetic experiments, we sort out changes of phenotype into the effects of heredity and environment. For this purpose language may be taken as consisting of three elements : the first is the scarcely changing basis, the stems of words, whose constancy is used in tracing the genealogy of languages. The second is a slowly changing part, the grammar, whose large changes follow a cycle merely differing in speed in different members of the Indo-European family and therefore providing poor evidence of genetic control. The third is the most rapidly changing part, that of sound, whose changes follow different lines in every language and even dialect. Phonetics is evidently the most promising starting-point.

Sound changes are of two kinds. The first may be described as changes of apportionment such as are covered by shifts and dissimilations. They often have, like grammatical changes, a cyclical and hence mechanical character depending on one another and on accent changes ; they are therefore again likely to be most indirectly related to the genetic conditions. The second kind of sound change is found in what we may call complement, or the total sound equipment of a people. As a question of complement we may probably include the existence of special sound combinations as well as of simple sounds in particular positions, such as the initial $R$ lost in Basque and the initial and inter-vocal $\mathrm{P}$ lost in Celtic languages. Within the European languages there are certain clear divergences in complement, as in $\mathrm{H}, \mathrm{TH}$ and $\mathrm{KH}$, while between them and more remote languages much greater differences occur. Change of complement can scarcely depend on fortuitous mechanical conditions. It is, on the other hand, most likely to depend on the inherent capacities of individuals to make the sounds concerned. It is with changes of complement, therefore, that we ought to begin our investigation.

It is, further, in Europe that we have the best chance of establishing our case, on account of our much greater knowledge of the present and past relationships of the peoples and languages of this region than of any other. 


\section{GENETIC PREMISES}

Before proceeding any further we must consider what differences, on grounds of our present knowledge of genetics, we are likely to find and how we may have to measure them. In the light of historical and contemporary observations, genetics would lead us to assume that we have in all parts of Europe a mixture of individuals of genotypes whose differences, in part adaptive to local geographical and cultural conditions and in part accidental, fall into two types of spatial variation: (i) clinal, to use Huxley's expression, that is, showing statistical gradients in respect of the proportions of individuals with contrasting characters; (ii) tribal or broken up into discontinuous groups by barriers to mating.

These conditions seem unfavourable for discovering any genetic influence on speech. Languages are obviously more homogeneous than peoples. In adopting a language, however, the individual subordinates himself to the community with which he wishes to communicate. The language must therefore be determined by the community whose genetic properties will be measurable statistically from individuals. We shall return to the statistical method later as a means of measuring relationship. First, however, we must consider the direct mechanism in the individual.

The mechanism concerned is the apparatus of voice production. It shows the highest degree of variation in man. What has hitherto been a personal observation can now, following the work of Luchsinger and Tarnóczy, be put in a scientific form. Although family resemblances are high, no two of us, apart from identical twins, are alike in voice. Some differences depend on hard external structure; others, like Sturtevant's difference in tongue rolling, no doubt depend on less obvious muscular and nervous control. Now it is a principle that all variable characters of a species (apart from those like sex and caste which are co-operative) will also vary absolutely or relatively, as between its subordinate endogamous groups, its races or tribes. There is therefore no reason to doubt that the observed differences in capacity for sound production amongst different races and nations of man have, in part, a genetic basis.

Such differences in capacity need be only very slight. They need merely suffice to establish preferences on a principle of economy or ease in speech which expresses itself in many linguistic rules. For example, by the principle of consonantal dissimilation one consonant of a group is altered to make the group as a whole easier to articulate. Meillet has pointed out the uniformity of the changes that result. This uniformity arises from a uniform difficulty for one people. What we are now concerned with are difficulties greater for one people than for another, difficulties which will lead to preferences in one and not in another, and hence to divergence. 
Thus we may explain, for example, the failure of the tribe of Ephraim to pronounce the word shibboleth correctly. That marginal tribe, we must assume, differed from its neighbour of Gilead in such a way that $\mathrm{SH}$ was not impossible but more difficult to articulate than S. The cause, whether the width of the tongue or the narrowness of the mouth, does not concern us. The consequence, the sound of $\mathrm{SH}$ being converted to $\mathrm{S}$ in their dialect, so that they "could not frame to pronounce it right " (Judges, xii, 6, A.V.) is what matters.

Many will object at this point that education will overcome these differences or difficulties. For a sufficiently insensitive ear this can appear to be true. But in fact the reverse argument is more important. The force of unconscious imitation is the most powerful discipline known to free peoples. We see this best in slave-owning societies, such as that of the southern United States, where the owners and the slaves, genetically dissimilar, by imitating one another, have produced in the course of 300 years a convenient intermediate compromise. By seeking their lowest common denominator, two non-combining groups in one community can thus reduce (but not abolish) the appearance of those limitations of speech which are inherent in each. But nearly all languages are produced by communities composed of a single combining group. Imitation within communities will then be between genetically similar individuals and will therefore serve to magnify differences between communities rather than reduce them. A slight, and indeed only statistically identifiable, genetic difference will establish a linguistic difference and, secondarily or mechanically, a linguistic divergence.

Genetic limitations and preferences would be expected to express themselves at all three levels, the individual, the group and the race or nation. The most direct expression of genetic character is seen of course in the individual. Impediments of speech are universal in infants and different for every infant in each family. Most of these impediments are overcome before maturity but a few remain in the adult. Particular impediments are characteristic of particular peoples speaking particular languages, their own or others. And these are found to affect retreating sounds, those for example, like $\mathrm{R}$ and $\mathrm{H}$ in English or $\mathrm{H}$ in Serbo-Croat, which are maintained and have even been restored, by the written word.

The group expresses its genetic character in dialect. In this respect dialect stands between the imaginary free speech of an individual and the standard or high language of a civilised nation. Dialect is most significant genetically: the group who make it are, in the first place, as close as we can get to a mating group, a unit of genetic recombination; in the second place, they are a group unrestrained by the conservative force of the written word with its traditional articulation whose effect we have just noted. The effect of inbreeding in promoting the proliferation of dialects is autocatalytic. For the dialects, once formed, prohibit outbreeding; they 
do so with equal success in the flat plains of Hungary and in the deep valleys of New Guinea.

The crucial importance of dialect for the genetic understanding of language is seen where a single standard language has been imposed by a single political and cultural agency on a people sharply divided genetically into two groups. Most European countries provide examples but the French division is best documented. The transition between southern and northern dialects is, as in England, a gradual one but, according to Meillet, if a boundary is drawn it has to run from Lyons to Bordeaux, not directly, but skirting the northern edge of the central massif. What does this speech boundary mean? It has been a cultural or political barrier at various times, in the days of the Langue d'Oc and of the Albigenses as well as of Vichy, but always as a result of invasions from beyond the Rhine. Although submerged by the political power, at one time of Rome, at another of Paris, it is the natural boundary between a fixed native population and one which has been subject to mixture with northern invaders. It is a genetic boundary.

When we reach the language level, what interests us is the newly imposed language. Its mechanics are revealed by the changes the negro slave has made in the different languages of his masters. Confronted with French his preference asserted itself, whether in rhythm or sound, by breaking it down into Creole, a new language. Confronted with English and Spanish he merely modified the sounds. As Johnson remarks (1926) : " the harsh ' ts' sound is displeasing to the negro ear as well as troublesome to the negro tongue, so it (dat's) is softened to 'das '." Similarly he generally reduces $\mathrm{TH}$ to $\mathrm{T}$ or $\mathrm{D}$. In both cases it is no doubt the tongue which prefers and adopts, and the ear which later approves, the easy course.

When we take a longer view, we see the imposed language revealing genetic action in two ways, by its divergence and by its instability. The new speakers change a language to fit their preferences in sound production. And when they themselves are genetically mixed, as they usually are, they themselves change and the language remains unstable for a long time. To the first cause we have to attribute the diversification of the Romance languages, and to the second, the instability of English or early Latin in contrast to the stability of Persian or Polynesian.

\section{THE VIEWS OF THE LINGUIST}

With these genetic principles in mind we can put a proper value on what linguists themselves have said. It is only recently that genetics has enabled us to distinguish between heredity and environment, or between genotype and phenotype. In the absence of either of these distinctions the linguist (and the social scientist likewise) has necessarily failed to put race and culture, or individual and group, in their proper 
relationship. His opinions in consequence have been diverse and sometimes confused. They may be represented by three conflicting examples.

My first example will be van Ginneken who has both propounded and illustrated the principle of genetic determinacy in language. His understanding of some of the consequences of hybridisation seems to be correct, and also of the temporary effect of a governing class : as he says "naturam expellas furca, tamen usque recurret." In consequence I believe that he intends his "revivals," or reciprocal changes in sounds, to have the precise socio-genetic interpretation that I shall put upon them. But when van Ginneken assumes, on the genetic side, polymeric factors, recombination, crossing-over and dominance, and, on the social side, a balance of individuals in segregation ratios with preferences for particular vowels, linguists and geneticists equally will find him hard to follow. He is taking over from the early Mendelians a mechanical naïveté, which is altogether useless in the field of language. His attack on the problem of circular sound changes in the Teutonic languages also seems to underestimate the difficulties I have alluded to earlier. On the other hand van Ginneken has collected facts which will be of great value to the later development of the subject. And he was the first to recognise the whole possibilities of the genetic approach to language " qui pour l'étude de l'hérédité humaine apportent un trésor inattendu de données."

The more sophisticated views of Meillet may be summarised as a second example by an extract in his own words (1925) :-

En apprenant une langue nouvelle, les sujets ne perdent pas pour cela leur hérédité. . . . On est amené ainsi à supposer que les innovations les plus caractéristiques du français tiendraient, non seulement à la façon dont le latin à été prononcé en Gaule, mais à une hérédité d'habitudes acquises par les sujets parlant gaulois. Avec cette forme de l'hypothèse, les objections que l'on fait souvent à la théorie du substrat se résolvent immédiatement. Le passage de $u$ fermé à $\ddot{u}$ sur le domaine gallo-roman et en Alsace ne serait pas une survivance immédiate du gaulois, mais l'effet lointain de certaines habitudes acquises transmises par hérédité.

Si l'explication-au moins partielle-de la diversité des formes prises sur différents domaines par une langue qui se généralise est souvent contestée, c'est qu'on envisage les faits d'une manière trop mécanique: il ne faut pas s'attendre à trouver dans la langue généralisée des particularités du "substrat" sous forme brute. L'action est complexe et se manifeste sous des formes au premier abord peu apparentes.

In these remarks three arguments are important :-

(i) The determinacy of development of language can be due only to the action of heredity.

(ii) This action is a long term effect operating on complex principles of its own and not by simple mechanical transference as many have supposed.

(iii) The heredity itself is the result of an acquired habit, the 
Gauls being thus condemned to speak French in a Gaulish manner by their habit of having spoken Gaulish earlier.

The first two arguments are entirely acceptable to modern genetics. It is only the third that is untenable. For assuming the inheritance of acquired characters, a linguist must not be blamed too much : a little Lamarckian superstition has been all the social scientist has had in the past to stand between him and the pit of racial error. The argument may, however, be inverted. Gaulish and French owe their parallel properties to the fact that they have been formed by the same people with almost the same heredity. Translating Meillet's views into modern genetics we should have to assume an ultimate genetic determination of language but a determination which is always imperfect because it operates on large and mixed populations over great periods of time during which these populations are themselves liable to change.

As a third example I will give the most distinguished representative of the opposite point of view to one I am proposing. Jespersen has recognised and defined the cultural relationships of the individual to the group. He could not, however, understand their genetic relationships. He recognised that his individuals differed in importance, being "commonplace" or " unique," but he could not recognise that they did so for genetic reasons. On the contrary he has explicitly denied the genetic, and even the structural foundations of language. Thus " the little differences which are of course found in the arching of the palate, in the size and form of the nasal chamber, etc., seem to have no significance whatever." And "the view that particular features of the pronunciation of Jews, or of Negroes in the Southern States of America, are due to racial peculiarities ... is certainly erroneous." And finally "the conditions governing changes in sounds in course of time . . . are everywhere the same."

In these ways, putting emphasis for lack of evidence, Jespersen resists the smaller cult of the "folk-mind" to embrace the larger mysticism of "the things common to all mankind." In doing so he puts the issue which I shall contest squarely before us. We have to answer one question: Do racial differences affect speech, or changes in speech, or have all the peoples of the earth the same potentialities and preferences for speech without regard to the different structural and mental characteristics inherent in them ?

\section{THE TH SOUND MAP}

The European sound complement varies most clearly, and the history of the variation can be traced most accurately, in respect of the TH sound. I therefore propose to use it as a pilot test and to illustrate methods and principles.

It will be convenient to group as TH the simple voiced and voiceless fricatives, the Saxon $\varnothing$, the Greek $\theta$ and the Basque compound 
TTH which is transliterated in Spanish as z. While recognising their affinity I shall exclude the aspirated dental of Sanskrit and Hindustani and the right- or left-tongued LL of Welsh. On this basis the distribution of TH in the world to-day, and the chief complementchanges that it has undergone in the past 3000 or even 6000 years, can be sketched with some certainty.

The present distribution of $\mathrm{TH}$ is strikingly non-fortuitous. Apart from an outlier in south-west Africa, the Herrero, it seems to be confined to the south and west periphery of the Eurasian continent. It exists in three zones-the European, the Arabic, the Dravidian with Burmo-Siamese ; or we might say approximately the Christian, the Islamic, and the Buddhist. The TH character thus overrides the genealogical divisions of language at the same time that it shows a certain historio-geographical consistency.

Our historical and pre-historical knowledge throws light at least on the first two of these zones. Common ancestors whether of languages or of peoples are no doubt more heterogeneous than we are led to suppose. But the common ancestral Indo-European language which seems to have arisen in the Danube basin seems also to have had the TH sound. Its western expansion brought it into contact with a TH-speaking Basque zone stretching, as place-names indicate, from Genoa to Bordeaux and Lisbon. In the east it met non-TH speakers including the forbears of the modern Finnish, Turkish and Paleosiberian groups. In consequence $\mathrm{TH}$ seems already to have changed into an aspirated dental in Sanskrit and to have disappeared in the whole eastern and central Aryan groups-Slavonic, Georgian, Armenian, Persian, Hindustani, etc. The one exception perhaps consists in a few isolated tribes of Dardic speakers in the Pamirs, who are perhaps the fair-haired Wakhi tribes described by Sir Aurel Stein.

The great Aryan expansion was followed in historical times, as we know, by a series of reverse movements into Europe of non-THspeakers. Although, outside Britain and the Balkans, these migrations have not greatly altered the distribution of languages, they must have changed the racial composition of the speakers of those languages. It is not surprising, therefore, that the $\mathrm{TH}$ sound has been lost in a band of invaded countries. The change was pre-historic in eastern Europe. Elsewhere it can be dated. It began in Italy and moved north through France and Germany to Sweden in the period from 300 B.C. to A.D. I 400 . The Celtic, Gothic, Illyrian, Venetic, Etruscan and Basque $\mathrm{TH}$ sounds were driven out of all these countries, with or without the languages to which they were attached. The prestige of a governing class had suppressed the TH sound in educated usage in the Latin-speaking part of the Roman Empire. After the overthrow of that empire, western Europe was confused phonetically as in other respects. There was a new sorting out of sounds. The whole of the Carolingian Empire lost its TH. In France there were flickerings of $\mathrm{TH}$ as seen in the French version of the Serments de 
Strasbourg in 842 . And to-day, according to van Ginneken, we find it in Savoie and Dauphiné and, in the Basque combination of TTH, in a region of Poitou. Beyond the Rhine $\mathrm{TH}$ receded in a wave which began in the ninth century in the south of Germany, reached the Baltic in the thirteenth, and submerged Friesland and most of Scandinavia in the fourteenth century.

In the mid-European belt TH survives to-day only in the archaic spelling of personal and place-names. TH survives, however, in the French as well as in the English spellings of such important latinised names as Bothnia, Lithuania (Lettow of Chaucer), Ruthenia, Carinthia and Carpathian to recall the broad but transient empire of the Goths. In German official spelling $\mathrm{TH}$ remained until the present century. In Friesian, on the other hand, it begins to disappear in documents of 1405 .

The fringe in which the $\mathrm{TH}$ sound remains to-day runs from Iceland through Britain to Spain and Greece. Again we see that it overrides the boundaries of linguistic genealogy. It unites Teutonic and Celtic in the north-west, Latin and Euskarian in the south-west, Greek and Albanian in the south. The phonetic unity makes itself heard through the verbal divergence.

In two areas the changes of TH repay more detailed study. In the British area we see a gradient or cline. Its maxima are in Iceland and Ireland, recalling an ancient commerce in women. It falls in dialect through Scotland and Wales to the north of England where the level is irregular but in general lower on the east side. It reaches a minimum in England nearest to the non-TH coast of France and also where Celtic place-names are fewest. The voiced TH becomes $\mathrm{D}$ in Sussex and Kent, in the Shetlands, and in the Yorkshire fisherman's dialect, and partly $\mathrm{F}$ or $\mathrm{V}$ in Cockney. In western Norway and Denmark it is reduced from a phoneme to a consonantal variable and indeed is entirely lost in most Fünen and Jutland dialects. Finally in Breton it expires altogether but it has reappeared (in place of $r$ ) in West Jersey. Historically there has perhaps been some decline in the TH of standard English since King Alfred's time.

These transitions in space and time reinforce what the general map of Europe tells us, namely, that $\mathrm{TH}$ is being pushed westwards as an effect of migration and without respect to the language, Celtic or Teutonic, which carries it.

The second most important area is that of the Iberian peninsula. Climatic and geographical as well as linguistic and historical evidence suggests that this region has been especially resistant to racial intrusion. The Latin language and later the rule of the Caliphate were successfully imposed on the people by numerically weak invaders. These two impositions by small governing classes assisted one another in suppressing for the time being the primitive $\mathrm{TH}$ sound which still survived in Basque. But in the central mass of Spain from the Asturias to Andalusia the racial character of the people, freed from foreign rule, 
reasserted itself. One hundred and fifty years after the Moors had been driven out $\mathrm{TH}$ reappeared. It did so in different ways in different parts. In Castille, about $\mathrm{I} 620, c, z$, and sometimes $d$ came to be pronounced as TH. In Andalusia $s$ underwent the same change. The preference was the same, but it expressed itself in different ways

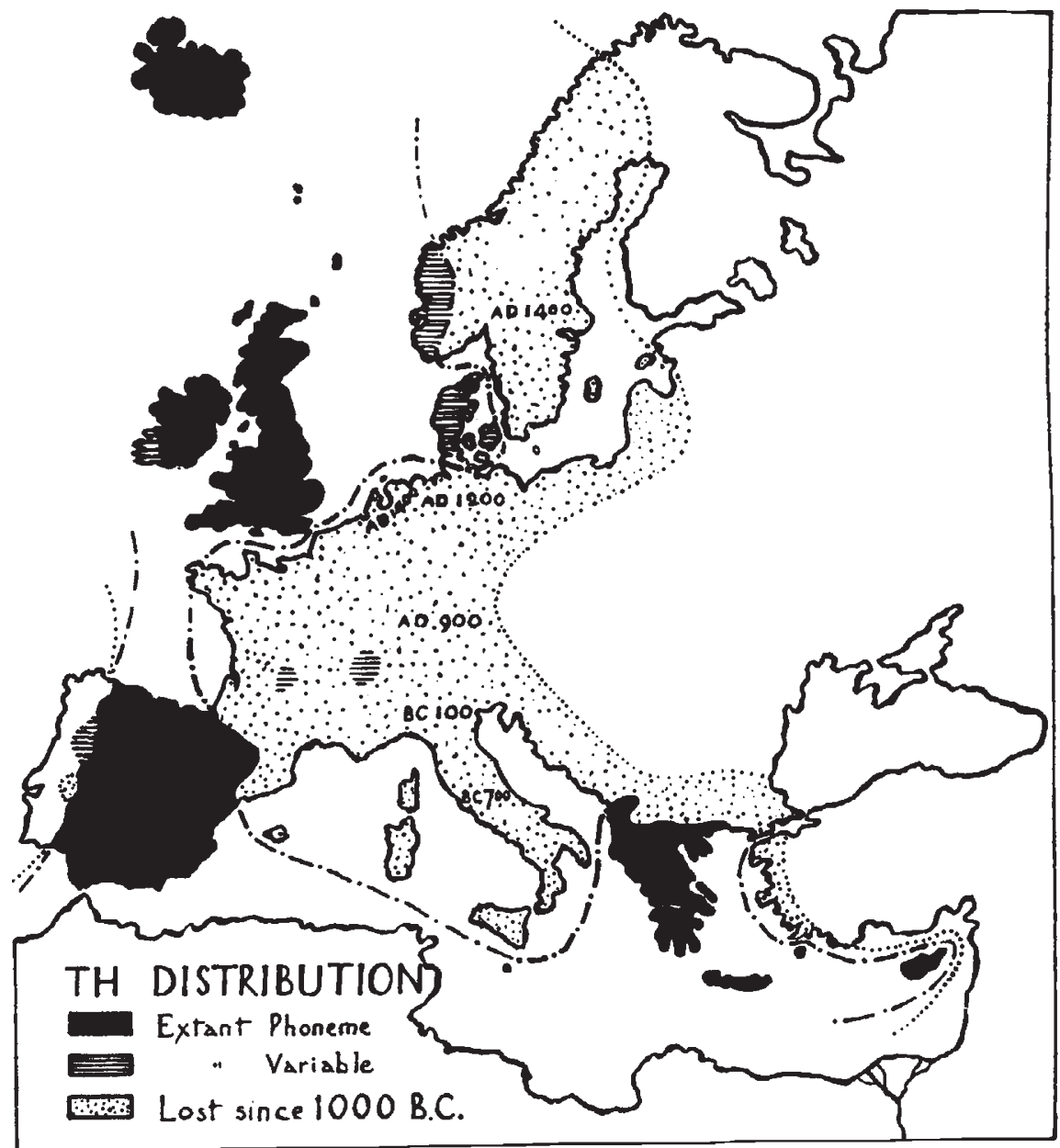

FIG. I.-TH sound map of Europe showing its division into three zones according to present frequency or past possession of the $\theta$ and $\delta$ sounds. The dates in the middle zone mark the time of loss. (References, Section A).

by etymological standards just as it does in the comparison of London, Manchester and Dublin.

In this phonetic rebirth the east and the west failed to join. Gatalan retained its concordance with Provençal and French, and Gallego with Portuguese. When, therefore, the New World came to be colonised by a mixture of Gallegos, Andalusians, Catalans, and even some non-Spaniards, it is not surprising that the Castillian lisp 
failed to gain control, failed to reach the threshold value for an addition to the sound complement. The racial compound in America was different from that in the Home Country, and their unity of speech has never been recovered.

Although the TH distribution is peripheral in Europe (and Asia),

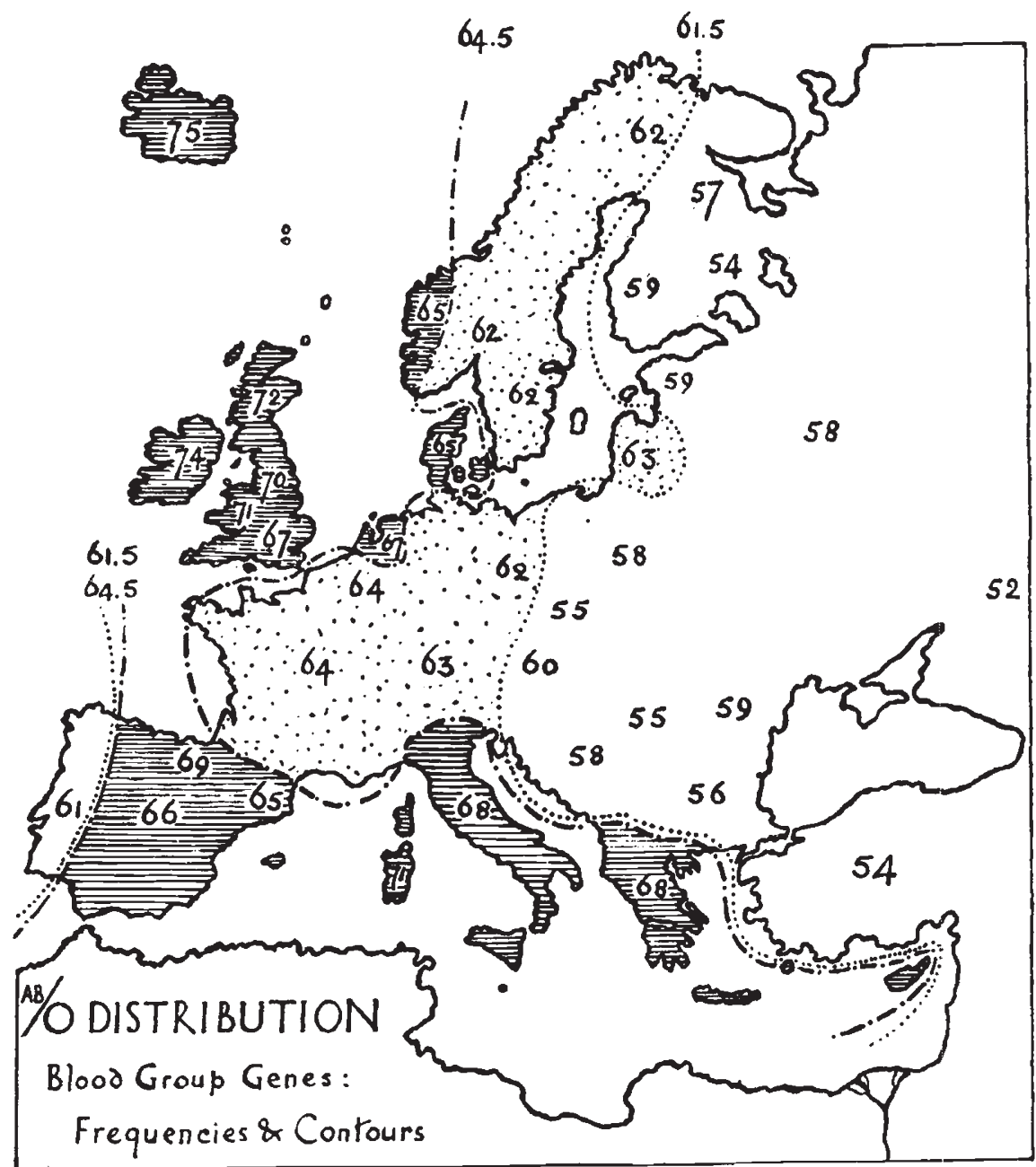

Fig. 2.-Blood group map of Europe showing the regular gradients and a division into three zones by contour lines at arbitrary values of O-gene frequency in the population (data from Boyd, 1939, and from the more recent local authorities, Section B).

there are, outside the TH ring, two vestiges of what we may call an anti-TH zone. The first and strongest development is that already mentioned in the west of the Peninsula, in Portugal and Galicia where a voiced TH occurs only as a consonantal variable in certain dialects and where the Castillian $c$ is unknown. The second is in the west of Ireland. It may be seen equally in the official Erse and in 
pockets of dialect from Kerry in the sout'west to Sligo in the nort'west. Its phonetic idiom is imitated in the song of 1688 , the Lilliburlero (in Percy's Reliques), thus :- "And he will cut de Englishmen's troate." This sentence expresses the opposite of the more characteristic east Irish habit of thrampling on the English. It seems to continue the anti-TH wave along the Atlantic fringe and may perhaps represent the tail-end of an ancient society which, prior to 400 B.c., ran along the coast from Africa and derived from the cultural relations that were so strongly developed in the Megalithic period. The reappearance of the anti-TH zone on the Asiatic fringe in Malaya likewise points to a very ancient survival.

The Arabic region has also something to tell us of the distribution of TH.

At the same time that TH speech was being pushed back in Europe a reverse expansion was taking place on the south side of the Mediterranean. The Islamic conquests entailed an expansion of the Arabic race and the Arabic TH. But this expansion depended on a rapid dilution of the conquering polygamous group by the overwhelming numbers of their converts and hybrids. This dilution was equally marked in its secondary and tertiary stages in the Kingdoms of Cordoba in 1490 and of Delhi in 1590 . The governing class so diluted was far smaller than Arabic enthusiasm imagines or the wearing of the green turban suggests. It is not surprising to find, therefore, that TH quickly disappeared even in Egypt and survives to-day only for academic and sacerdotal purposes in the accents of the educated few.

A third example of $\mathrm{TH}$ expansion has likewise proved abortive. Classical Hebrew, like classical Arabic, has an important TH sound. But the modern Hebrew of Palestine spoken by Ashkenazim Jews has (so Mr J. Catford tells me) lost the sound. Here we have two possible explanations, and the alternative is of great interest. Is the loss due to racial contamination with the non- $\mathrm{TH}$ speakers of the bygone Russian and Turkish empires? Or is it due to the cultural example of the Russian and Turkish speech? The condition is too recent (and therefore perhaps too transient) to enable us to say.

Summing up : the distribution of $\mathrm{TH}$ in Europe is intelligible in terms of the available evidence from history and pre-history including our knowledge of place-names and the inferences of the origin of the Indo-European system of languages in central Europe. It favours a greater stability of populations than most historians and philologists have been inclined to assume. And it suggests that the mass of the people ultimately come to express their genetic character by the sounds of their language even when a governing class is able to impose the word basis. The value of $\mathrm{TH}$ in this consideration is merely that the European populations are mostly close to the threshold which divides its expression from its suppression and are consequently apt to change from one to the other under the influence of migration and 
conquest. It can therefore be used as a marker to indicate gradients in the population of the whole continent through its frequency, its existence as a phoneme, and its time of origin or extinction. Such gradients correspond to the clines which genetics recognises as characteristic of the natural geographical populations of polymorphic species. We have therefore to discover whether, on independent evidence, any other clines can be mapped for man in the region we are considering.

\section{THE BLOOD GENE MAP}

The question is now as to whether any other genetic gradients in man agree with that of TH. A character is needed with a comparable appearance of selective neutrality. When I began my enquiries no such characters were sufficiently known in man. Adaptive clines like those for pigmentation in Europe are obvious enough. Others, too, like that for colour-blindness (Vernon and Straker, 1943), may have an adaptive taint. Now, however, in the blood groups we are beginning to have what we want.

We may regard the $\mathrm{A}, \mathrm{B}$ and $\mathrm{O}$ blood group genes as possible markers of three homologous segments of chromosome which are near neutrality in effect. Since the three are independent, in the sense that each has no single alternative, the percentages of the different types of chromosome $\mathrm{A}, \mathrm{B}$ or $\mathrm{O}$ in the population of each region of Europe give three frequency-maps, showing contours and gradients. For small and backward regions such blood group maps are bound to be defective as yet, but they are accurate within the necessary one per cent. for the large and advanced ones. Amongst them the $\mathrm{O}$ group map (which has not hitherto been traced) shows the kind of agreement with the history of migrations that we are looking for. In general it suggests a movement from the east driving $\mathrm{O}$ into the periphery. Its contours enable us to divide Europe into three O-gene zones :-

(i) A peripheral zone from Iceland to Greece with 65 to 75 per cent.

(ii) An intermediate zone from Sweden to France with $6 \mathrm{r} \cdot 5$ to $64 \cdot 5$ per cent.

(iii) Two zones, a main eastern zone and the Portuguese corner, with 6 I per cent. or less.

What relation have these zones with TH distribution? The first zone comprises all the TH-positive countries. The second zone comprises nearly all those countries which had $\mathrm{TH}$ and have now lost it. The third zone comprises those countries which have not had any recorded pronunciation of $\mathrm{TH}$ during the last 2000 or 3000 years.

The agreement between blood group and phonetic zones is complete except for Italy and Holland, which are 2 or 3 per cent. over 65 . Their peoples should not therefore have lost their TH as 
Italy did already at the time when the Latin language replaced the Greek, Celtic, Venetic and Etruscan tongues (I00-400 B.c.), and as Holland did rooo years later.

The salient feature of this agreement is perhaps the Portuguese depression. But no less significant are those finer details which can be detected only in Britain. Here the $\mathrm{O}$ cline crosses the island in close keeping with the $\mathrm{TH}$ position in dialect, reaching its lowest level in the south-east. In Europe as a whole the $\mathrm{O}$ contours, like the TH zones, agree with the distribution of the great language families only in so far as these agree with our historic and pre-historic knowledge of migrations.

Thus the $\mathrm{O}$ and TH maps agree more closely than the apparently confused history of Europe would seem to justify us in predicting. The isogens are almost exactly equatable with the isophons.

\section{GENES IN SOCIETY}

Having answered the question whether the genes act on speech we may now ask ourselves the quite independent question of how they do so. The problem divides itself, apart from the anatomical and physiological aspects already discussed, into the strictly genetic and the social aspects.

First let us take the genetic aspect.

The validity of the genetic component of language is supported by these first trials. What philologists have described as the substratum effect must be due to the integrated action of the genotypes of populations differing in their sound preferences as individuals. Galton, Fisher, and most recently Mather, have shown how to detect and measure in families and populations the inheritance of properties which are not demonstrable in single individuals. Now it seems possible to show the inheritance of properties which, owing to the slowness of the effects of social integration, are not even demonstrable in the contemporary life-times of a multitude of individuals. Yet this slow social integration must be the basis of all relations of race with culture. In studying human heredity experimental technique has once again to be aided by elaborate statistical constructions and the novelty of the result depends largely on the method.

It might have been that language was a purely cultural convention like the rules of mating. These rules (although inherently consistent within tribes) can have no primarily genetic basis ; but their genetic consequences are so great that they must have been exposed to strong natural selection. This selection has evidently favoured out-breeding since it has left only rare vestiges of inbreeding in Southern Asia.

Language, it now seems, is in just the opposite position. It has a decided genetic basis but hardly any selective value. If the TH character had a selective value, owing for example to its suitability to a maritime climate, it could hardly show the peculiar distribution 
we find. In the absence of a selective value we can consider whether it is determined by a polygenic balance or by a single gene complex. Either could match the blood group distribution and either could reflect ancestral origins. Selective neutrality would, however, do nothing to favour the development of a gene complex which must always be adaptive and, on the other hand, a polygenic basis is more likely for what is probably a quantitative character. Just such a correlation as is required between a major gene effect in the blood and a polygene effect on the tongue has been described in man where $4 \mathrm{I} \cdot 2$ per cent. of diabetics are taste-blind and only $25^{\circ} 9$ per cent. of non-diabetics (Terry and Segall, I947).

The social aspect of the problem has been the subject of expert study which has the same results whether it is approached with a genetic hypothesis or, as Jespersen has done, without one. With the genetic situation in mind, however, we can interpret the results with more confidence and express them with more precision. Clearly the more variation there is amongst individuals (owing to hybridisation), the more unstable their language will become. And the more unstable a language, the more choice every maturing individual will have amongst alternative sounds to use. These sounds will differ in their local, their social, and their age classes. In making this choice the commonplace or unique individual (as Jespersen puts it), or rather the differing genotypes (as I put it), will have different parts to play. Further, on my view, the instability of the language will arise from a genetic difference between the people who made the language and the people who are now using it.

To put it in another way : my view is an expression of the genetic axiom that the properties of individuals are determined by the reaction of genotype and environment. But this axiom is modified by a special circumstance, namely, that the genotypes of individuals themselves interact to produce an environment by an integration in space and an accumulation in time. This environment is what we call culture. The discontinuities between nations and between languages that we see in Europe are the steps cut in continuous genetic slopes by discontinuous cultures.

The combination of methods and assumptions I have used for a selected and apparently trivial comparison gives us the means of opening a new field of enquiry. It is a field of incomparable richness for the study of man. It can provide a co-ordinating hypothesis capable of advancing the studies of language, of human genetics, of society and of culture in general, both now and before recorded history. It can provide a first means of evaluating the modes of integration of the masses of dissimilar genotypes which constitute classes, races and nations, modes of integration which underlie the development of all human culture. In doing these things its discipline offers a corrective to the ingenuous theories (or fairy tales) which in the past have done less to help science than to embroil nations. And 
it requires neither the repudiation nor the exaltation of race but assumes a continuity underlying the tribal variation of man which more superficial methods have overlooked or disowned.

\section{SUMMARY}

I. The determinacy of development of language has been widely recognised. Some linguists have used genetic assumptions to explain this determinacy. Others have rejected these assumptions because they rested on too little or reached too far.

2. Modern population genetics, however, enables us to understand the relations of genotype to phenotype and of the individual to the group or race in a way that removes these objections.

3. Specific preferences for sound production are the most immediately profitable field of study. The $\mathrm{TH}$ sound is taken as an example. Its present distribution in Europe and Asia and its changes during the last 3000 years agree with the evidence of human migrations and conquests. The sound map also agrees with the A B O blood group frequency contour map in Europe. The Isophons follow the Isogens (figs. I and 2).

4. This method of comparative and historical, phonetic and genetic study makes it possible to apply rigorous biological conceptions to a wide field in the social sciences.

In considering the present distribution of the TH sound I am indebted to many colleagues in all parts of Europe and Asia for information. I am, however, particularly indebted to Prof. Menéndez Pidal of Madrid, to Mr S. G. West and his colleagues of The British Council in Lisbon, Mr J. Catford, member of the International Phonetic Association, Mr David Abercrombie of Leeds University, Mr Oswald Harland of Wetherby, Prof. M. J. Sirks of Gröningen University, Dr R. R. Race and Dr A. E. Mourant of the Lister Institute for references and advice.

NotE.-Since going to press $I$ have received a detailed account of blood groups in France (M. H. V. Vallois, 1944, Bull. Soc. Anthrop. 5, 53-80), which indicates that a high $O$ gene belt ( 66 to 68 per cent.) runs across Central France from the Basque Country. This zone includes van Ginneken's TH-speaking areas.

\section{REFERENCES}

BARTSCH, K. 1903 .

\section{A. Speech}

Chrestomathie de l'ancien français. VIII -XVe Siècles. Leipzig. (6th Edn.)

BELGERI, L. I 929 .

Les affriquées en italien et dans les autres principales langues européennes.

Trieste (planche 5I-carte de l'Europe affriquée).

BORRICHIUS, O. 1675 .

De causis diversitatis linguarum dissertatio. Copenhagen.

ENTWISTLE, W. J. 1936 .

The Spanish Language. Faber, London.

JAKOBSON, R. I 942 .

The Palæosiberian languages.

Am Amthrop. 44, 602-620. 
JESPERSEN, OTTO. $\quad 1946$.

Mankind, Nation and Individual from a linguistic point of view.

Allen \& Unwin, London. (Reprint of Oslo Edn. 1925.)

Johnson, J. W. 1926.

The Book of American Negro Spirituals. (Preface).

Chapman \& Hall, London.

LUCHSINGER, R. I940.

Die Sprache und Stimme von ein- und zwei-eiigen Zwillingen in Beziehungen zur Motorik und zum Erbcharakter.

Arch. 7. Klaus Stift. 15, 461-527.

MEILLET, A. 1925.

La méthode comparative en linguistique historique.

Inst. Sammenlignende Kulturforsk, Oslo.

PIDAL, R. MENÉNDEZ. Ig29.

Origenes del Español. Madrid.

TARNóczY, T. H. 1947.

Physical characteristics of speech sounds and some aspects of their anthropological relations.

VAN GINNEKEN, J. 1927.

Die Erblichkeit der Lautgesetze.

Indogermanische Forsch., 45, 1-44.

VAN GINNEKEN, J. 1933.

La Biologie de la Base d'Articulation. (Psychologie du Langage).

7. Psych. (Paris), 3o, 266-320.

\section{B. Blood}

BOYD, W. C. $\quad$ I939.

Blood groups.

Tab. Biol. (Hague) I7, 11 3-240.

CARRION, J., and HERNANDEZ, J. 1943.

Contribución al estudio de los grupos sanguineos en España.

An. Inst. Esp. Hematol. y Hemater. I, I53-1 $5^{8}$.

DOBson, A: M., and IKIN, E. W. 1946 .

The A B O groups, etc.

7. Path. and Bact. 58, $221-227$.

HART, E. W. I 944 .

An analysis of the blood group composition of a population in Northern Ireland. Ann. Eugen. 12, 89-101.

haRTMANN, O., and Lundevall, J. U. 1944 .

Blood group distribution in Norway.

Skr. norske VidenskAkad. No. 2, 7-68.

\section{General}

DARLINGTON, C. D. 1943.

Race, class, and mating in the evolution of Man.

Nature, Lond. 152, 315-317.

FISHER, R. A., and TAYLOR, G. L. I940.

Scandinavian influence in Scottish ethnology.

Nature, Lond. 145, 590. 
HUXLEY, J. S. I 942 .

Evolution, the Modern Synthesis. London.

ROBERTS, J. A. FRASER. 1942.

Surnames and blood groups.

Nature, Lond. 144, r $047-8$.

SIRKS, M. J. $\quad 1937$.

Klang, Stimme und Laut im Geltungsbereich der Vererbungslehre.

Mélanges van Ginneken $1-16$.

STEIN, AUREL. $\quad$ I 933 .

On Ancient Central-Asian Tracks. Macmillan, London.

STURTEVANT, A. H. I940.

A new inherited character in man (tongue-turning).

P.N.A.S. 26, 100-102.

TERRY, M. C., and SEGALL, G. 1947.

The association of diabetes and taste-blindness.

7. Hered. $3^{8}$, $135^{-1} 37$.

VERNON, P. E., and STRAKER, A. I943.

Distribution of colour-blind men in Great Britain.

Nature, Lond. 152, 69 o. 